\title{
Institutional quality, economic development and illegal logging: a quantitative cross-national analysis
}

\author{
Matthias Bösch ${ }^{1}$ (D)
}

Received: 27 November 2020 / Revised: 9 March 2021 / Accepted: 20 April 2021 / Published online: 7 May 2021

(c) The Author(s) 2021

\begin{abstract}
Illegal logging is a global concern, associated with severe negative environmental, social and economic impacts, such as deforestation, degradation of biodiversity and loss of government revenues. Despite recent international efforts to combat illegal logging activities, the problem remains widespread. While the academic literature on the subject is extensive, little systematic research has been devoted to analysing the causes of illegal logging. Here, this knowledge gap is addressed with a cross-national assessment of factors hypothesized to impact illegal logging. The logistic regression analysis conducted in this study corroborates some widely held beliefs, but also provides some new insights on the factors that are important for whether illegal logging is likely to be a problem. It is shown that, besides physical-geographic characteristics, a number of factors relating to the level and speed of a country's economic-institutional development are associated with illegal logging. These include gross domestic product per capita, economic growth, voice and accountability, rule of law and control of corruption. The findings also have implications for existing policies to tackle illegal logging activities.
\end{abstract}

Keywords Governance $\cdot$ Corruption $\cdot$ Rule of law $\cdot$ Voice and accountability $\cdot$ Deforestation $\cdot$ Logistic regression

\section{Introduction}

Illegal logging is a global issue that affects both developing and developed countries (e.g. FAO 2001; Contreras-Hermosilla 2002; Smith 2004; Alemagi and Kozak 2010). It often leads to forest degradation and/or deforestation, thus threatening not only valuable forest ecosystem services and biodiversity, but also the welfare of those dependent on forest resources for their livelihoods (e.g. Hansen and Treue 2008; Reboredo 2013; Vasco et al. 2017; Bösch et al. 2018). In addition, illegal logging and the related timber trade deprive governments of important tax revenues, distort timber prices and hamper investments in the formal forest sector (e.g. Tacconi 2007b; Li et al. 2008; Hoare 2015; Kleinschmit et al. 2016a). At the same time, illegal logging may also be connected to a general climate of lawlessness in which other illegal activities (e.g. poaching and illegal wildlife trade,

Communicated by Martin Moog.

Matthias Bösch

matthias.boesch@thuenen.de

1 Thünen Institute of International Forestry and Forest Economics, Leuschnerstr. 91, 21031 Hamburg, Germany drug trafficking, money laundering) are facilitated (Glastra 1999; Seneca Creek Associates and Wood Resources International 2004a).

The issue has been gaining prominence in international policy discussions since the 1990s. For instance, illegal logging was included in the 1998 G8 Action Programme on Forests (Humphreys 2006; Hoare 2015). In 2003, the European Union (EU) adopted the Forest Law Enforcement, Governance and Trade (FLEGT) Action Plan with the aim of reducing illegal logging activities by strengthening legal forest management, improving governance and encouraging trade in legally sourced timber (Dieter 2009; Hoare 2015). In 2008, the USA amended the Lacey Act of 1900 with the adoption of the Legal Timber Protection Act (LTPA). Soon afterwards, similar laws were introduced in the EU and Australia: the EU Timber Regulation (EUTR) in 2010 and the Australian Illegal Logging Prohibition Act (ILPA) in 2012. All three legislations prohibit the import of timber harvested in contravention to the laws of the country of origin (Lambin et al. 2014; Leipold and Winkel 2016; Leipold et al. 2016). However, despite these global efforts to combat illegal logging over the last few decades, recent studies indicate that the problem remains widespread. According to Nellemann and Interpol Environmental Crime Programme 
(2012), illegal logging comprises as much as $15-30 \%$ of total worldwide logging. Hoare (2015) reports that the share of illegal timber in international trade has remained roughly the same since the turn of the century. Thus, further actions and international collaboration are required to combat the problem (Kleinschmit et al. 2016a).

Understanding the causes of illegal logging is a necessary prerequisite to improve existing policy measures (or design new ones). Given its far-reaching environmental, social and economic implications, surprisingly little systematic research has been devoted to analysing the general causes of illegal logging. Most of the existing information about the causes of illegal logging activities in the literature is based on anecdotal evidence (e.g. from context-specific stakeholder interviews) or appears to be speculative. A few country-level studies (e.g. Palmer 2001; Smith et al. 2003; McElwee 2004; Hansen and Treue 2008; Alemagi and Kozak 2010; Miller 2011) and multi-country reports (e.g. Karsenty 2003; Seneca Creek Associates and Wood Resources International 2004a; Contreras-Hermosilla et al. 2007; Hoare 2015; Kleinschmit et al. 2016b) assume factors such as corruption, conflicts and population growth to be general causes of illegal logging. However, these assumptions have not yet been empirically evaluated. This is the objective of the present study.

A quantitative cross-national study appears to be wellsuited to generate some robust insights on the factors that are associated with illegal logging. Specifically, I build a logistic regression model and test a series of literature-based hypotheses. In doing so, I aim at answering the following research questions: Are there some generalizable lessons on why some countries are affected by illegal logging, while others are not? Are there identifiable aggregate-level factors that are related to the illegal harvesting of wood? It is worth mentioning that this study will not present new evidence on illegal logging in particular countries. Instead, I use currently available information on national illegal logging rates to see whether I can find common patterns across countries and attempt to derive policy recommendations regarding global illegal logging. In addition, due to the necessary level of aggregation for such a study, the analysis will not be sensitive to subnational variation in illegal logging, different forest types and different patterns of wood use (e.g. Burgess 1993; Barbier et al. 2019).

\section{Methods and data}

\section{Defining illegal logging}

There is no internationally agreed definition of illegal logging. Existing definitions range from a rather narrow understanding referring to logging outside concession boundaries or extracting more timber than authorized, to broad definitions including all activities of timber processing, transporting and trading in violation of national (or subnational) laws (e.g. Kleinschmit et al. 2016a). While especially nongovernmental and governmental organizations tend to differ in their assessment of what constitutes illegal logging, many studies and reports acknowledge the multifaceted and complex nature of illegal logging activities and agree that there is not just one type but various types of illegal logging (e.g. Turner et al. 2008; Kleinschmit et al. 2016a). Sometimes, illegal logging is equated with unsustainable timber harvesting practices. However, this is not always true. Logging may technically be illegal, yet sustainable, or legal, yet unsustainable (Contreras-Hermosilla et al. 2007).

The clandestine nature of illegal logging makes it difficult to find accurate and reliable data on its scope (e.g. Brack 2005; Contreras-Hermosilla et al. 2007). Nevertheless, country-specific case studies (e.g. Palmer 2001; Hansen and Treue 2008) as well as assessments at the multiple-country level (e.g. Seneca Creek Associates and Wood Resources International 2004a; Lawson and MacFaul 2010; Hoare 2015) publish from time to time detailed figures on the extent of illegal logging and the related timber trade. Usually, these estimates show a large variation, depending on the year of investigation, the definition of illegal logging, but also on the methods used (Kleinschmit et al. 2016a). Thus, it is often not possible to directly compare these estimates (for details, see for example Seneca Creek Associates and Wood Resources International 2004a; Hansen and Treue 2008; Dieter 2009; Gan et al. 2016).

For the present study, it is essential to use a dataset that is as consistent and comprehensive as possible. Therefore, I rely on the extensive list by Li et al. (2008) with illegal logging rates for industrial roundwood for almost all countries of the world. Most of the information in the list by Li et al. (2008) is based on the influential study by Seneca Creek Associates and Wood Resources International (2004a). This independent assessment used expert interviews conducted in the producer countries to derive illegal logging rates. ${ }^{1}$ The estimates in the list by $\mathrm{Li}$ et al. (2008) refer to a rather narrow definition of illegal logging, originally employed in the assessment by Seneca Creek Associates and Wood Resources International (2004a). This definition involves four types of illicit activities: (1) harvesting without authority in designated national parks or forest reserves; (2) harvesting without authorization or in excess of concession

\footnotetext{
${ }^{1}$ Illegal timber trade was estimated with wood flow (import source) analysis, i.e. by multiplying illegal logging rates from the expert interviews by trade volumes reported in official statistics (for details on the methodology, see Seneca Creek Associates and Wood Resources International (2004a: 1-4)).
} 
permit limit; (3) failing to report harvesting activities to avoid royalty payment or taxes; and (4) violation of international trading rules or agreements, such as export bans or CITES. This clear definition covers most of the concerns raised by the international community and thus appears to provide an appropriate perspective for the purpose of this study (e.g. Turner et al. 2007; Dieter 2009).

The list by $\mathrm{Li}$ et al. (2008), with estimates for the year 2004, constitutes the most recent information available on illegal logging rates for a large sample of countries. The study has often been used as a basis for applied research on illegal logging (e.g. Turner et al. 2008; Dieter 2009; Dieter et al. 2012). Yet, several aspects imply a certain degree of data uncertainty: first, expert interviews come with some limitations. For instance, the validity of the illegal logging estimates depends on the selection of experts in the different countries and their knowledge of the subject (Gan et al. 2016). Moreover, it is possible that interview responses may be influenced to some extent by different cultural backgrounds (e.g. Scheuch 1993; Buil et al. 2012; Hoare 2015). Second, Li et al. (2008) supplemented the data for a few countries by estimates from other studies (i.e. Miller et al. 2006; Contreras-Hermosilla et al. 2007). ${ }^{2}$ Third, Li et al. (2008) did not publish point estimates, but upper and lower bound estimates (i.e. a range of percentages) of illegally logged industrial roundwood (subdivided into sawlogs and pulpwood). I therefore decided to follow the approach taken in the deforestation studies by Deacon (1994) and Rudel and Roper (1996, 1997b) for addressing data imprecisions and used the information from the list to construct a binary measure of illegal logging as either high or low in a country.

For the statistical analysis, I followed Li et al. (2008), Turner et al. (2008), Dieter (2009) and Dieter et al. (2012) and first combined the information for sawlogs and pulpwood. For this purpose, I calculated the weighted average of the rates for sawlogs and pulpwood based on their respective production quantities in the different countries in 2004. This resulted in upper and lower bound estimates of illegal logging rates for industrial roundwood. ${ }^{3}$ Then, I took the upper bound (i.e. the less conservative) estimates and constructed a dichotomized measure of the illegal logging rates as being either "high" (more than $25 \%$ of total production from illegal sources; value $=1$ ) or "low" (less than $25 \%$ of

\footnotetext{
${ }^{2}$ In detail, estimates from Miller et al. (2006) were taken for Bangladesh, Costa Rica, China, Estonia, Latvia, Papua New Guinea and Peru. Estimates from Contreras-Hermosilla et al. (2007) were taken for Albania, Azerbaijan, Benin, Bolivia, Brazil, Bulgaria, Cambodia, Colombia, Ecuador, Georgia, Ghana, Indonesia, Mozambique, Honduras, Malaysia, Myanmar, Nicaragua and Russia.

${ }^{3}$ I calculated the arithmetic mean of these upper and lower bound estimates to construct a continuous dependent variable, which is used for a robustness check in the discussion.
}

total production from illegal sources; value $=0$ ) in a country. I chose $25 \%$ as a cut-off point, as only very few countries have scores close to it (Rudel and Roper 1997b). Moreover, this cut-off point also seems reasonable to make sure that only illegal logging activities of a nature or degree warranting international attention are considered (Seneca Creek Associates and Wood Resources International 2004a). Due to lack of reliable data, seven countries listed by Li et al. (2008) had to be excluded from the analysis (Cuba, Djibouti, North Korea, Somalia, Syria, Venezuela and Yemen). The final sample includes 163 countries (see "Appendix 1"): 100 countries (61.3\%) have low levels of illegal logging (e.g. Argentina, Australia, Botswana, Lithuania, Sri Lanka, Thailand), while 63 countries (38.7\%) are affected by high illegal logging according to my definition (e.g. Brazil, Bulgaria, Estonia, Ghana, Indonesia, Russia). This is in line with estimates by Toyne et al. (2002) and Tacconi (2007c), which indicate that illegal logging is a problem in about 70 countries around the world. ${ }^{4}$

\section{Explanatory variables}

The selection of potential explanatory variables is based on an extensive literature review. This means that I scrutinized the illegal logging literature (e.g. Seneca Creek Associates and Wood Resources International 2004a; Contreras-Hermosilla et al. 2007; Tacconi 2007a; Hoare 2015; Kleinschmit et al. 2016b) to identify those factors that have been assumed to be causes of illegal logging in one or more publications. In the following sections, I discuss all included variables in detail (see also Table 1). To avoid possible bias due to the influence of extreme values I used variables averaged out over the period 2000-2004. Table 2 presents sample descriptive statistics.

\section{Aspects of institutional quality}

The literature points to several aspects of poor institutional quality (or governance) that may lead to increased illegal logging activities in a country. Six dimensions seem to be particularly important:

First, it has been suggested that nations with low levels of democracy and accountability may have relatively high levels of illegal logging activities (e.g. Palmer 2001; Contreras-Hermosilla 2002; Kleinschmit et al. 2016a). This is because non-democratic governments do not have to be as

\footnotetext{
${ }^{4}$ Neither Toyne et al. (2002) nor Tacconi (2007c) explicitly name the countries that have issues with illegal logging. Yet, the book edited by Tacconi (2007a) includes case studies from the illegal logging hotspots Bolivia, Brazil, Cameroon, Honduras, Indonesia and Nicaragua. All of these countries are affected by "high" illegal logging according to my definition.
} 
Table 1 Explanatory variables (averaged out over the period 2000-2004)

\begin{tabular}{|c|c|c|c|}
\hline Variable & Description & Exp. sign & Source \\
\hline Voice and accountability & $\begin{array}{l}\text { Higher values correspond to better outcomes (scaled to lie } \\
\text { between }-2.5 \text { and }+2.5 \text { ) }\end{array}$ & - & WGI (2018) \\
\hline Political stability and absence of violence & $\begin{array}{l}\text { Higher values correspond to better outcomes (scaled to lie } \\
\text { between }-2.5 \text { and }+2.5 \text { ) }\end{array}$ & - & WGI (2018) \\
\hline Government effectiveness & $\begin{array}{l}\text { Higher values correspond to better outcomes (scaled to lie } \\
\text { between }-2.5 \text { and }+2.5 \text { ) }\end{array}$ & - & WGI (2018) \\
\hline Regulatory quality & $\begin{array}{l}\text { Higher values correspond to better outcomes (scaled to lie } \\
\text { between }-2.5 \text { and }+2.5 \text { ) }\end{array}$ & - & WGI (2018) \\
\hline Rule of law & $\begin{array}{l}\text { Higher values correspond to better outcomes (scaled to lie } \\
\text { between }-2.5 \text { and }+2.5 \text { ) }\end{array}$ & - & WGI (2018) \\
\hline Control of corruption & $\begin{array}{l}\text { Higher values correspond to better outcomes (scaled to lie } \\
\text { between }-2.5 \text { and }+2.5 \text { ) }\end{array}$ & - & WGI (2018) \\
\hline GDP per capita & $\begin{array}{l}\text { Gross domestic product per capita, PPP (ln; constant } 2017 \text { inter- } \\
\text { national \$) }\end{array}$ & - & World Bank (2021) \\
\hline Economic growth & Gross domestic product growth rate ( $\%$ annual change) & $+1-$ & World Bank (2021) \\
\hline Exports of industrial roundwood & Exports of industrial roundwood $\left(\mathrm{m}^{3} ; \%\right.$ of world total $)$ & + & FAO (2021) \\
\hline Population growth & (\% annual change) & + & World Bank (2021) \\
\hline Tropical climate & $\begin{array}{l}\text { Land area that has any of the four Köppen-Geiger tropical } \\
\text { climates }(\%)\end{array}$ & + & Nunn and Puga (2012) \\
\hline Forest area & (million ha) & + & FAO (2021) \\
\hline
\end{tabular}

Table 2 Descriptive statistics (variables are averaged out over the period 2000-2004)

\begin{tabular}{llllr}
\hline Variables & Mean & Standard deviation & Min & Max \\
\hline Voice and accountability & -0.061 & 0.975 & -2.064 & 1.626 \\
Political stability and absence of violence & -0.082 & 0.968 & -2.268 & 1.696 \\
Government effectiveness & -0.018 & 0.981 & -1.805 & 2.178 \\
Regulatory quality & -0.020 & 0.958 & -2.111 & 1.918 \\
Rule of law & -0.079 & 0.996 & -1.757 & 1.971 \\
Control of corruption & -0.058 & 1.013 & -1.538 & 2.436 \\
GDP per capita & 8.989 & 1.232 & 6.578 & 11.498 \\
Economic growth & 4.371 & 3.445 & -6.663 & 30.602 \\
Exports of industrial roundwood & 0.611 & 2.670 & 0.000 & 31.050 \\
Population growth & 1.480 & 1.331 & -1.240 & 6.268 \\
Tropical climate & 38.986 & 44.723 & 0.000 & 100.000 \\
Forest area & 24.288 & 84.929 & 0.000 & 809.077 \\
\hline
\end{tabular}

responsive to environmental activism as democratic governments (lack of electoral accountability). Moreover, such activism is usually less pronounced in non-democratic countries due to lower levels of freedoms like press, speech and assembly (e.g. Ehrhardt-Martinez et al. 2002; Shandra et al. 2011). Consequently, consultation with citizens in decisions related to environmental problems such as illegal logging is less likely in non-democratic countries.

Second, illegal logging activities are assumed to be facilitated in periods of political crisis and armed conflict (e.g. Karsenty 2003; Seneca Creek Associates and Wood Resources International 2004a; Alemagi and Kozak 2010; Pokorny et al. 2016). This is not least because people usually face shorter time horizons and higher discount rates during periods of war and political instability, and thus log as fast and as much as they can to maximize profits and minimize risk (Burgess et al. 2015). Moreover, armed groups are frequently reported to cut down trees in conflict zones to buy weaponry or to fund other illicit activities (Richards et al. 2003; Burgess et al. 2015).

Third, the literature mentions that countries with weak government institutions may have higher levels of illegal logging. In particular, a lack of government capacity (or willingness) to develop and enforce laws and regulations is believed to contribute to illegal harvesting of wood (e.g. Seneca Creek Associates and Wood Resources International 2004a; Contreras-Hermosilla et al. 2007; Tacconi 2007b). Such situations may be exacerbated when there 
are overlapping responsibilities between central and lowerlevel governments, for instance, due to poorly implemented decentralization processes (Richards et al. 2003; Tacconi 2007c; Hoare 2015).

Fourth, an incoherent legislative and regulatory framework is assumed to lead to illegal logging (e.g. Richards et al. 2003; Tacconi 2007c; Hoare 2015; Pokorny et al. 2016). In many countries, environmental and forestry laws are described as unclear, outdated, constantly changing and/ or playing only a marginal role (e.g. Palmer 2001; Brack 2003; Zimmerman and Kormos 2012; Pokorny et al. 2016). As a result, such laws are open to individual interpretation and easier to bend, thus providing incentives for illegal harvesting of wood (Tacconi 2007b).

Fifth, countries where the rule of law is weak or inoperable are assumed to provide fertile ground for illegal logging, as investigations may be delayed and many crimes go unpunished (e.g. Seneca Creek Associates and Wood Resources International 2004a; Brack 2005; Hansen and Treue 2008; Schloenhardt 2008; Alemagi and Kozak 2010). Moreover, long-term investments in sustainable forest management may be discouraged in countries where the rule of law is weak and property rights are not protected (e.g. ContrerasHermosilla 2002; Contreras-Hermosilla et al. 2007).

Sixth, the presence of corruption is frequently mentioned as a possible explanation for illegal logging activities (e.g. Palmer 2001; Richards et al. 2003; Smith et al. 2003; McElwee 2004; Alemagi and Kozak 2010; Miller 2011; Sikor and To 2011). Corruption in the forestry sector can take different forms, ranging from relatively low-level activities such as bribing officials to allow illegal timber through checkpoints ("petty corruption"), to more serious offences involving large sums of money ("grand corruption"), for example, paying bribes to politicians for the allocation of logging concessions (Hoare 2015; Pokorny et al. 2016; Meehan and Tacconi 2017; Sommer 2017, 2018).

The extent to which (1) low levels of democracy and accountability, (2) political crises and conflicts, (3) weak government institutions, (4) an incoherent legislative and regulatory framework, (5) a weak rule of law and (6) corruption are associated with illegal logging is investigated by using the six indicators of the Worldwide Governance Indicators (WGI) project of the World Bank (WGI 2018)

1. The "voice and accountability" indicator captures "perceptions of the extent to which a country's citizens are able to participate in selecting their government, as well

\footnotetext{
5 The WGI measure the quality of governance based on more than 30 underlying data sources that report the views and experiences of people from around the world on the quality of various aspects of governance (Kaufmann et al. 2011).
}

as freedom of expression, freedom of association and a free media" (Kaufmann et al. 2011).

2. The "political stability and absence of violence" indicator captures "perceptions of the likelihood that the government will be destabilized or overthrown by unconstitutional or violent means, including politically motivated violence and terrorism" (Kaufmann et al. 2011).

3. The "government effectiveness" indicator captures "perceptions of the quality of public services, the quality of the civil service and the degree of its independence from political pressures, the quality of policy formulation and implementation, and the credibility of the government's commitment to such policies" (Kaufmann et al. 2011).

4. The "regulatory quality" indicator captures "perceptions of the ability of the government to formulate and implement sound policies and regulations that permit and promote private sector development" (Kaufmann et al. 2011).

5. The "rule of law" indicator captures "perceptions of the extent to which agents have confidence in and abide by the rules of society, and in particular the quality of contract enforcement, property rights, the police and the courts, as well as the likelihood of crime and violence" (Kaufmann et al. 2011).

6. The "control of corruption" indicator captures "perceptions of the extent to which public power is exercised for private gain, including both petty and grand forms of corruption, as well as 'capture' of the state by elites and private interests" (Kaufmann et al. 2011). ${ }^{6}$

All six indicators are scaled to lie between -2.5 and 2.5, with higher values corresponding to better outcomes. Therefore, negative coefficients are expected in the regression: improved voice and accountability, more political stability, higher government effectiveness, improved regulatory quality, better rule of law and improved control of corruption are all thought to correspond with lower levels of illegal logging.

\section{Gross domestic product per capita}

It is suggested that lower national incomes and poverty are associated with higher levels of illegal logging (e.g. Hiller et al. 2004; Seneca Creek Associates and Wood Resources

\footnotetext{
${ }^{6}$ An alternative for corruption would be the Corruption Perceptions Index (CPI) of Transparency International. However, this index has much fewer country observations for the period 2000-2004 than the WGI "control of corruption" indicator. The same is true for disaggregated corruption data (e.g. the Quality of Government Institute [Dahlberg et al. 2020)], which account for both grand corruption in the executive sector and petty corruption in the public sector (for recent applications, see, for example, Sommer $(2017,2018))$.
} 
International 2004a; Tacconi 2007c; Alemagi and Kozak 2010; Islam and Sato 2012). This is explained by the fact that in low-income countries people are more likely to focus on extractive (i.e. consumptive) values of forests than on non-extractive and preservation values. Therefore, people in poorer countries can be generally expected to be more tolerant, or approve, of illegal logging activities than people in richer countries (Tacconi 2007b). A nation's level of wealth is thus assumed to be negatively related to illegal logging. To address this hypothesis, I use gross domestic product (GDP) per capita adjusted for purchasing power parity. These data, which are logged (ln), are obtained from the World Bank (2021) and measured in constant international dollars.

\section{Economic growth}

The literature points to two possible effects of national economic growth on illegal logging, the net consequence of which is uncertain (e.g. Tacconi 2007c; Pokorny et al. 2016). On the one hand, it is suggested that high economic growth rates stimulate domestic demand for timber and forest products, such as pulp and paper. Potentially, this could also increase illegal commercial harvesting (Pokorny et al. 2016). Therefore, a positive relationship between economic growth and illegal logging would be expected. On the other hand, high economic growth rates (often coupled with a rising number of attractive employment opportunities in other sectors) may also draw people away from the forest and from working with (illegal) logging operations-usually dangerous jobs done by the poorest people (Tacconi 2007d). This would imply a negative relationship between economic growth and illegal logging. In summary, the ex-ante expectations as to the effect of a country's economic growth rate on illegal logging are ambiguous. The data on annual growth rates of GDP are obtained from the World Bank (2021).

\section{Exports of industrial roundwood}

International timber trade is frequently reported to support illegal logging activities, especially in reports by non-governmental organizations (e.g. Glastra 1999; Brack 2005; WWF 2005; Tacconi 2007b; Schloenhardt 2008; Köthke 2020). The logic is that not only domestic demand drives illegal commercial harvesting, but globalization leads to new prospects for exports to non-environmentally sensitive markets that demand timber without considering whether it was harvested illegally (Tacconi 2007b). A variable capturing the extent to which a country is integrated into international trade is thus expected to be positively related to the level of illegal logging. I use data on global market shares of industrial roundwood exports (i.e. a country's exports of industrial roundwood divided by total world exports of industrial roundwood) provided by the FAO (2021) to address this hypothesis.

\section{Population growth}

As suggested by neo-Malthusian theory, population growth leads to a higher demand for land and natural resources and thus also to a potential increase in illegal logging activities (e.g. Seneca Creek Associates and Wood Resources International 2004b; Hoare 2015; Pokorny et al. 2016). In addition, a growing population is also suggested to affect illegal logging indirectly through labour markets by creating an abundant supply of labour and pushing down wage rates. In such situations, illegal logging operators may find it easier to recruit labour among the otherwise unemployed (e.g. Seneca Creek Associates and Wood Resources International 2004b; Islam and Sato 2012). For these reasons, population growth is expected to be positively related to illegal logging operations in a country. This hypothesis is addressed using annual population growth rates provided by the World Bank (2021).

\section{Tropical climate}

Illegal logging activities affect forests in many parts of the world, but forests in tropical regions are commonly considered a key target (e.g. Seneca Creek Associates and Wood Resources International 2004a; Hansen and Treue 2008; Gan et al. 2016). This is not least because many tropical timber species, such as mahogany, teak, rosewood and ebony, have higher commercial values than others because of their cultural values and unique physical and chemical properties (e.g. colour, texture, durability of wood). The higher value generates higher incentives for illegal commercial harvesting and trade (e.g. Richards et al. 2003; Shandra et al. 2011; Gan et al. 2016). ${ }^{7}$ A variable capturing the fraction of a country that has a tropical climate is thus expected to be positively related to the level of illegal logging. I use data from Nunn and Puga (2012) on the percentage of the land area of each country that has any of the four Köppen-Geiger tropical climates to address this hypothesis.

\section{Forest area}

Illegal logging activities can be expected to be more widespread in countries with large forest areas, simply because there might be more opportunities to log illegally (Smith 2004; Shandra et al. 2012). In fact, the physical nature of forest, i.e. vastness and the unbounded nature, may lead to public unconcern about the forest environment and create an

\footnotetext{
7 Unfortunately, there is no detailed information on timber species and associated values for the large sample of countries in this study.
} 
impression of forests as a free common good for everyone (Kant and Redantz 1997; Geist and Lambin 2002; Culas and Dutta 2003). In such a setting, people may have perceptions that illegal logging is not a harmful and/or a criminal activity (Tacconi 2007c). Moreover, it is conjecturable that controlling agencies in countries with vast forests away from public scrutiny may have more difficulties in monitoring forest operations (Contreras-Hermosilla 2002). In order to capture such possible variations between countries that are not covered by the other variables, a scaling variable is included by using a country's forest area as an explanatory variable. The data are obtained from the FAO (2021).

\section{Regression model}

As described above, the list with illegal logging rates by $\mathrm{Li}$ et al. (2008) is used to construct a dichotomized measure of illegal logging as either high or low in country $i$ in the year 2004. Logistic (or logit) regression is a regression technique specifically designed for dichotomous dependent variables, i.e. variables taking on a value of either 1 or 0 (for recent applications, see for example Zbinden and Lee 2005; Béguin et al. 2011; Zanella et al. 2014; Bösch et al. 2019). ${ }^{8}$ The dependent variable $y_{i}$ can be formally described as:

$y_{i}=\left\{\begin{array}{l}1, \text { if illegal logging is high } \\ 0, \text { if illegal logging is low }\end{array}\right.$

Let $x_{i}$ be a $k^{*} 1$ vector of explanatory variables, $\beta_{0}$ a constant, and $\beta^{\prime}$ a $k^{*} 1$ vector of unknown coefficients. The probability of high illegal logging $\operatorname{Prob}\left(y_{\mathrm{i}}=1\right)$ can be written as:

$\operatorname{Prob}\left(y_{i}=1\right)=p=\frac{e^{\beta_{0}+\beta^{\prime} x_{i}}}{1+e^{\beta_{0}+\beta^{\prime} x_{i}}}$

The estimation form of the model is then given after the logit transformation:

$\operatorname{logit}(p)=\ln \left(\frac{p}{1-p}\right)=\beta_{0}+\beta^{\prime} x_{i}$

${ }^{8}$ Note that, due to the dichotomous scale of the dependent variable, there is no assumption of homoscedasticity or equality of variance (e.g. Pampel 2000; Menard 2010).

\section{Results}

The results of the logistic regression, along with the appropriate test statistics, are illustrated in Table $3 .{ }^{9}$ Both McFadden's and Nagelkerke's pseudo- $R^{2}$ suggest fairly good fits, as they are well within the range of about 0.2 to 0.4 typically estimated for logistic regression models (e.g. Harper et al. 1990; Zbinden and Lee 2005). Likelihood ratio test statistics exceed the critical $\chi^{2}$ value at the $1 \%$ level in all six model specifications. Each model specification contains one of the six measures of institutional quality: voice and accountability (Specification 1), political stability and absence of violence (Specification 2), government effectiveness (Specification 3), regulatory quality (Specification 4), rule of law (Specification 5) and control of corruption (Specification 6). These specifications are used for two reasons. First, multicollinearity problems are avoided. When all six measures of institutional quality are included together in the analysis, variance inflation factor scores for these six indicators are greater than 10 , indicating potential problems with multicollinearity (e.g. Tabachnick and Fidell 2013). This is probably due to the high bivariate correlations among these variables (see "Appendix 2"). Yet, the highest variance inflation score is less than 3 in models where the effect of these variables is investigated separately, indicating no potential problems with multicollinearity. Second, the use of alternative model specifications is generally considered a useful tactic in crossnational regression analysis: the sequential use of "cognate" but "distinct" indicators of similar theoretical constructs can help to provide further insights on the complexity of the issue under investigation and increase the reliability of the findings (e.g. Shandra 2007; Shandra et al. 2008).

As anticipated, the coefficients that represent the six measures of institutional quality are found to be negatively signed, i.e. higher levels of institutional quality correspond with lower levels of illegal logging. Three measures of institutional quality are found to be statistically significant: the coefficient for voice and accountability is significant at the $5 \%$ level, and the coefficients for rule of law and control of corruption are significant at the $10 \%$ level. The coefficients for political stability and absence of violence, government

\footnotetext{
${ }^{9}$ Except for their signs, logistic regression coefficients are hard to interpret directly. Interpretation in terms of odds ratios is usually considered the most intuitive way. Odds ratios are obtained by simply exponentiating the coefficients, that is, calculating $\exp (\beta)$. For quantitative variables, it is helpful to subtract 1 from the odds ratio and multiply by 100 , that is, calculate $100(\exp (\beta)-1)$. This yields the percentage change in the odds for each one-unit increase in the independent variable (e.g. Pampel 2000; Allison 2012). For instance, the estimated odds ratio of 0.490 for voice and accountability (Specification 1) indicates that a one-unit increase in this indicator is associated with a $51.0 \%$ decrease in the predicted odds of illegal logging.
} 
Table 3 Logistic regression results

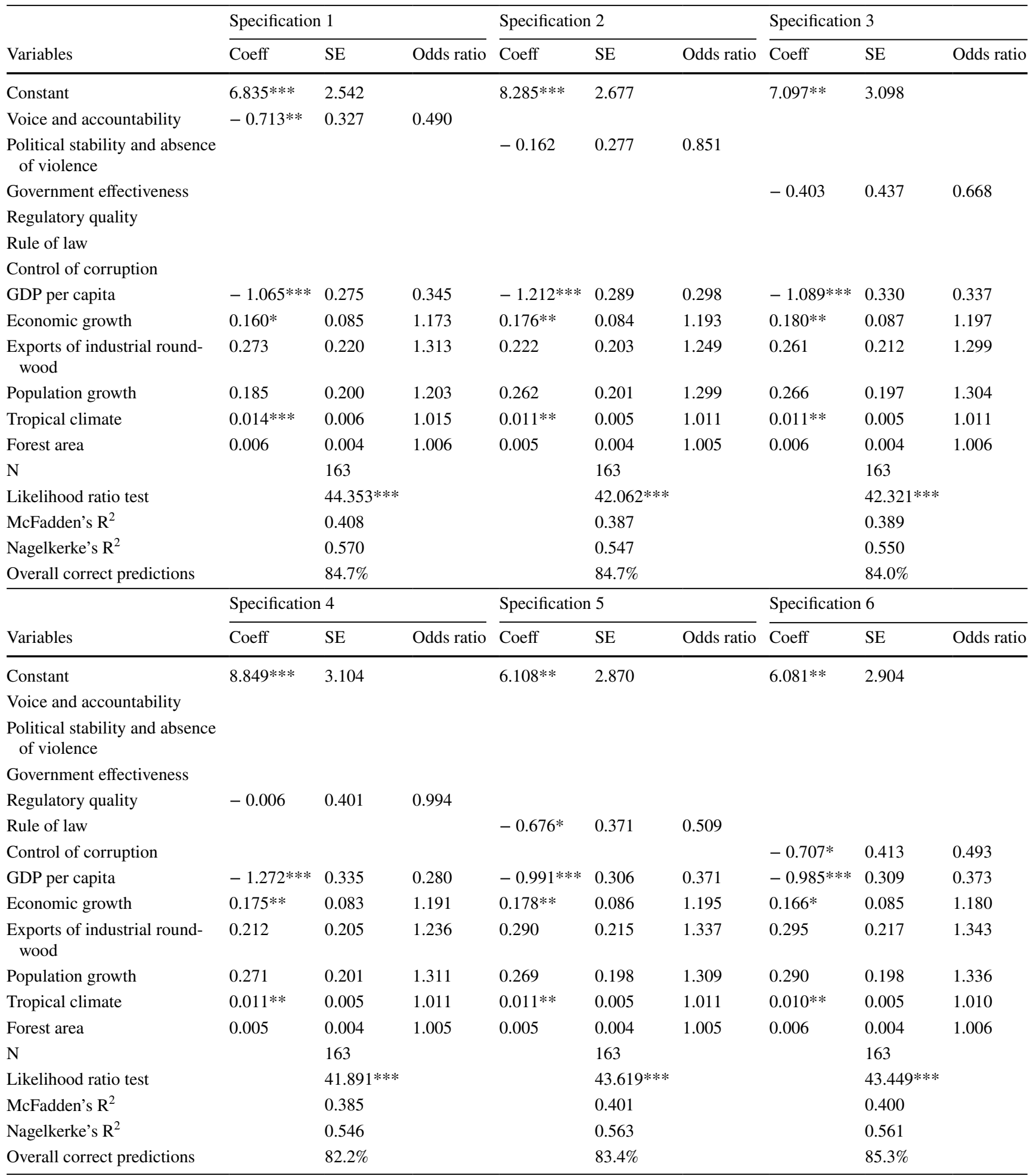

*Significant at the $10 \%$ level

**Significant at the $5 \%$ level

***Significant at the $1 \%$ level 
effectiveness and regulatory quality fail to achieve a level of statistical significance.

As expected, the coefficients for GDP per capita are negative and significant at the $1 \%$ level in every model specification. ${ }^{10}$ In all six model specifications, the coefficients for economic growth are positively signed - the ex-ante expectations here were ambiguous. This finding suggests that the effect of higher domestic demand for timber and forest products in a growing economy is likely to be more important than the opposing effect of more attractive employment opportunities in non-forest sectors. The coefficients for economic growth are significant at the 5\% level in Specifications $2-5$ and significant at the $10 \%$ level in Specifications 1 and 6.

The coefficients for exports of industrial roundwood are positively signed as hypothesized, but are non-significant in all six model specifications. Likewise, the coefficients for population growth are positive as expected, but do not reach a level of statistical significance in any model specification. ${ }^{11}$ As hypothesized, the coefficients for the tropical climate variable are positively signed and significant at the $1 \%$ level in Specification 1 and at the 5\% level in Specifications 2-6. The coefficients for forest area are positive as anticipated, but are non-significant in all six model specifications. ${ }^{12}$

\section{Discussion and conclusions}

Over the past two decades, the international community has increasingly focused on illegal logging and its negative environmental, social and economic impacts. Major international bodies such as the World Bank, the United Nations Forum on Forests and the G8 have identified illegal logging as a serious threat to the world's forests (e.g. Kaimowitz 2003; Ravenel and Granoff 2004; Brack 2005; Kleinschmit et al. 2016a). While there have been numerous quantitative analyses investigating the causes of deforestation (e.g. Angelsen and Kaimowitz 1999; Geist and Lambin 2002), most of the

\footnotetext{
$\overline{10}$ I replaced GDP per capita with other development-related variables, i.e. degree of urbanization and level of HDI (Human Development Index). The coefficients for both variables are negative and statistically significant in all model specifications. The other findings are similar to the results presented in Table 3. I do not present the results here for the sake of space.

${ }^{11}$ I used different indicators to reflect the general concept of population pressure, i.e. total population and population density rather than population growth. The coefficients for these variables fail to reach statistical significance. The other findings are similar to the results reported in Table 3 (not shown here for the sake of space).

12 I reran the models using land area instead of forest area. The coefficients for this variable are non-significant. The other findings remain similar to the results reported in Table 3 (not presented here for the sake of space).
}

existing information about the causes of illegal logging is anecdotal or speculative. To my knowledge, this study is the first quantitative research effort to analyse the factors that are associated with global illegal logging. The results of the cross-national logistic regression corroborate some widely held beliefs, but also provide some new insights on the issue.

There are a few caveats to consider. Generally, the results, as presented in this manuscript, should be interpreted with reasonable care. This is, first of all, due to the simple and somewhat imprecise measurement of the dependent variable. As a robustness check of the results, I replaced the binary dependent variable with a continuous one (i.e. the arithmetic mean of the upper and lower bound estimates of illegal logging rates for industrial roundwood, as described in the section "Methods and data") and used the same set of model specifications. The detailed results for the ordinary least squares (OLS) regressions are shown in "Appendix $3 "$. The coefficients for all variables that were found to be significant at the $10 \%$ level or better in the logistic regression remained statistically significant at the $10 \%$ level or better in the OLS regression. Moreover, the OLS regression confirmed the non-significant findings of the logistic regression. Thus, it appears that the results of this study are fairly robust, given the data limitations, the complexity of the problem being analysed and the high level of aggregation of the analysis. Yet, it should be emphasized that an explanatory variable found to be significant in the regression does not automatically mean that it is a cause of illegal logging in every country. In the first place, regression analysis tests correlations between a set of explanatory variables and a dependent variable-correlations do not necessarily imply causal relationships. In addition, an explanatory variable found to be significant in the regression points to a general pattern across countries, which is likely to hold for most countries, but exceptions to this pattern are possible (e.g. Tole 1998; Angelsen and Kaimowitz 1999).

Furthermore, this study was carried out with highly aggregated national-level data, although illegal logging activities may not necessarily take place in the entire country. The Russian Far East, for instance, is reported to have much higher illegal logging rates than the western part of the country (Nellemann and Interpol Environmental Crime Programme 2012; Gan et al. 2016). In other cases, the conditions that force people to cut down trees illegally may extend well beyond the boundaries of individual nation states (Rudel and Roper 1997a; Contreras-Hermosilla 2002). Thus, there is probably some mismatch in scale between explanatory preconditions and illegal logging on the ground, which is inevitable in the context of such a cross-national study. However, it is still justifiable to consider countries as relatively homogeneous units, especially with regard to the institutional-economic dimensions that appear to influence 
illegal logging activities (Rudel and Roper 1997b; Tallis et al. 2009; Bösch et al. 2019).

The results of this study indicate that physical-geographic characteristics are important for where illegal logging is likely to be a problem. On average, countries in the tropics are more likely to suffer from illegal logging activities than others. This is not least because these countries typically offer more opportunities for the illegal commercial harvesting of high-value species. Somewhat surprisingly, I did not find that the extent of forest area is related to illegal logging. Likewise, I did not find support for neo-Malthusian theory, suggesting that population growth has an effect on illegal logging activities.

A series of factors relating to the level and speed of a country's economic-institutional development turned out to be of great importance for whether illegal harvesting of wood is likely to be a problem. Higher levels of economic development (i.e. GDP per capita) were found to be significantly associated with lower levels of illegal logging. The analysis also supports the hypothesis that high economic growth rates are related to increased illegal logging. This is consistent with the notion that commercialization and growth of timber markets as driven by domestic demands lead to increased illegal logging. In contrast, the level of foreign demand and the extent to which a country is integrated into the international trading system were found to be less important. This finding indirectly supports recent evidence that the majority of illegal timber is consumed in domestic markets and does not enter international trade (e.g. Hoare 2015; Gan et al. 2016).

Three dimensions of institutional quality turned out to be significantly associated with illegal logging: voice and accountability, rule of law and control of corruption. These results do not come unexpectedly since numerous studies have identified a lack of democracy, the presence of corruption and a weak rule of law as important impediments to progress in reducing illegal logging. Yet, I found no support for the idea that government effectiveness and regulatory quality are associated with illegal logging activities. Likewise, higher political stability is not significantly related to lower levels of illegal logging. This finding indirectly supports recent evidence that the impact of conflicts and wars on forests may be much more complex than commonly assumed (Burgess et al. 2015; Landholm et al. 2019). Note also that there is no significant correlation between a country's intentional homicide rate (as a proxy for overall violence) and illegal logging (see "Appendix 2"), despite numerous reports of criminal violence in the context of illegal logging in recent years (e.g. Reboredo 2013; van Solinge 2014).

For future research, it seems obvious that more up-todate estimates about illegal logging and the associated timber trade are urgently needed. Moreover, longitudinal data on illegal logging would allow the development of more sophisticated models to further check the robustness of the results. Then, one could also conduct separate analyses for each region of the world. This would allow to determine whether there are regional variations in the pattern of results presented in this research. Yet, the findings of this study should preferably also be confirmed in studies with disaggregated data at subnational (e.g. local, provincial) levels. This would also allow to consider the role and motivations of different actors (e.g. large-scale commercial logging companies versus small-scale subsistence users of wood) as well as their social and cultural values. In addition, the effects of conflicts, domestic migration and labour market dynamics (e.g. the number of employment opportunities in the informal sector) on illegal logging could be investigated in more detail.

Finally, what are the policy implications of the findings? At least in the short run, most of the factors that were found relevant for illegal logging activities can hardly be influenced by policy makers (e.g. governments, international organizations, conservation groups and the private sector). Yet, in the longer run, institutional problems like corruption can certainly be tackled, e.g. through measures such as reducing the discretionary power of government officials, removing subsidies or administratively fixed prices or opening up the economy to foreign competition (e.g. FAO 2001; Smith et al. 2003). However, it seems obvious that solving the problem of illegal logging will take more than just addressing institutional problems alone. Strategies aimed at reducing the supply of illegal timber need to consider the complex interplay between the physical-geographic, economic and institutional factors identified in this study-and are thus difficult and time-consuming to implement. Moreover, such strategies will most likely overlap with broader development strategies outside the forest sector and thus require coordination across sectors (e.g. World Bank 2006).

By its very nature, illegal logging is hard to detect. In this context, this research points to the factors that make the presence of illegal logging activities likely: for instance, high economic growth rates, high levels of perceived corruption and a weak rule of law are an indication that illegal harvesting of wood might be more of a problem than elsewhere. Policy makers and stakeholders involved in the fight against illegal logging should thus place their focus on countries with the identified framework conditions. Furthermore, the results of this analysis could contribute to determining the degree of risk of the country of origin-a procedure which is for instance required in the due diligence practice of operators (i.e. importers of timber and forest products) under the EU Timber Regulation (Leipold 2017). 
Appendix 1: Countries included (IL = 0 means low illegal logging, and IL $=1$ means high illegal logging in 2004)

\begin{tabular}{|c|c|c|c|c|c|c|c|c|c|c|c|}
\hline Country & IL & Country & IL & Country & IL & Country & IL & Country & IL & Country & IL \\
\hline Afghanistan & 0 & Canada & 0 & Georgia & 1 & Latvia & 0 & Pakistan & 1 & Swaziland & 1 \\
\hline Albania & 1 & Cape Verde & 0 & Germany & 0 & Lebanon & 0 & Panama & 0 & Sweden & 0 \\
\hline Algeria & 1 & $\begin{array}{l}\text { Central African } \\
\text { Rep. }\end{array}$ & 1 & Ghana & 1 & Lesotho & 0 & $\begin{array}{l}\text { Papua New } \\
\text { Guinea }\end{array}$ & 1 & Switzerland & 0 \\
\hline Angola & 1 & Chad & 1 & Greece & 0 & Liberia & 1 & Paraguay & 0 & Tajikistan & 0 \\
\hline Argentina & 0 & Chile & 0 & Guatemala & 0 & Libya & 1 & Peru & 1 & Tanzania & 0 \\
\hline Armenia & 0 & China & 1 & Guinea & 1 & Lithuania & 0 & Philippines & 1 & Thailand & 0 \\
\hline Australia & 0 & Colombia & 0 & Guinea-Bissau & 1 & Macedonia & 0 & Poland & 0 & Togo & 1 \\
\hline Austria & 0 & $\begin{array}{l}\text { Congo Dem. } \\
\text { Rep. }\end{array}$ & 1 & Guyana & 0 & Madagascar & 1 & Portugal & 0 & Tonga & 0 \\
\hline Azerbaijan & 1 & Congo Rep & 1 & Haiti & 0 & Malawi & 1 & Qatar & 0 & $\begin{array}{l}\text { Trinidad \& } \\
\text { Tobago }\end{array}$ & 0 \\
\hline Bahamas & 0 & Costa Rica & 1 & Honduras & 1 & Malaysia & 1 & Romania & 0 & Tunisia & 1 \\
\hline Bahrain & 0 & Cote d'Ivoire & 1 & Hungary & 0 & Mali & 1 & Russia & 1 & Turkey & 0 \\
\hline Bangladesh & 1 & Croatia & 0 & Iceland & 0 & Malta & 0 & Rwanda & 1 & Turkmenistan & 0 \\
\hline Barbados & 0 & Cyprus & 0 & India & 0 & Mauritania & 1 & $\begin{array}{l}\text { Saint Vincent } \\
\text { \& G. }\end{array}$ & 0 & UAE & 0 \\
\hline Belarus & 0 & Czech Rep & 0 & Indonesia & 1 & Mauritius & 1 & Samoa & 0 & Uganda & 1 \\
\hline Belgium & 0 & Denmark & 0 & Iran & 0 & Mexico & 0 & Sao Tome \& P. & 1 & Ukraine & 0 \\
\hline Belize & 0 & Dominica & 0 & Iraq & 0 & Moldova & 0 & Saudi Arabia & 0 & UK & 0 \\
\hline Benin & 1 & Dom. Republic & 0 & Ireland & 0 & Mongolia & 0 & Senegal & 1 & Uruguay & 0 \\
\hline Bhutan & 0 & Ecuador & 0 & Israel & 0 & Morocco & 0 & Serbia \& M & 0 & USA & 0 \\
\hline Bolivia & 1 & Egypt & 1 & Italy & 0 & Mozambique & 1 & Sierra Leone & 1 & Uzbekistan & 0 \\
\hline $\begin{array}{l}\text { Bosnia-Herze- } \\
\text { govina }\end{array}$ & 0 & El Salvador & 0 & Jamaica & 0 & Myanmar & 1 & Singapore & 0 & Vanuatu & 0 \\
\hline Botswana & 0 & $\begin{array}{c}\text { Equatorial } \\
\text { Guinea }\end{array}$ & 1 & Japan & 0 & Nepal & 0 & Slovakia & 0 & Vietnam & 1 \\
\hline Brazil & 1 & Estonia & 1 & Jordan & 0 & Netherlands & 0 & Slovenia & 0 & Zambia & 1 \\
\hline $\begin{array}{l}\text { Brunei Darus- } \\
\text { salam }\end{array}$ & 0 & Ethiopia & 1 & Kazakhstan & 0 & New Zealand & 0 & $\begin{array}{c}\text { Solomon } \\
\text { Islands }\end{array}$ & 0 & Zimbabwe & 0 \\
\hline Bulgaria & 1 & Fiji & 0 & Kenya & 1 & Nicaragua & 1 & South Africa & 0 & & \\
\hline Burkina Faso & 1 & Finland & 0 & Korea, Rep. & 0 & Niger & 1 & Spain & 0 & & \\
\hline Burundi & 1 & France & 0 & Kuwait & 0 & Nigeria & 1 & Sri Lanka & 0 & & \\
\hline Cambodia & 1 & Gabon & 1 & Kyrgyzstan & 0 & Norway & 0 & Sudan & 1 & & \\
\hline Cameroon & 1 & Gambia & 1 & Laos & 1 & Oman & 0 & Suriname & 0 & & \\
\hline
\end{tabular}


Appendix 2: Pearson's correlation coefficients between the model variables and development-related variables Human Development Index (HDI), urbanization and intentional homicides (coefficients significant at $5 \%$ are in bold)

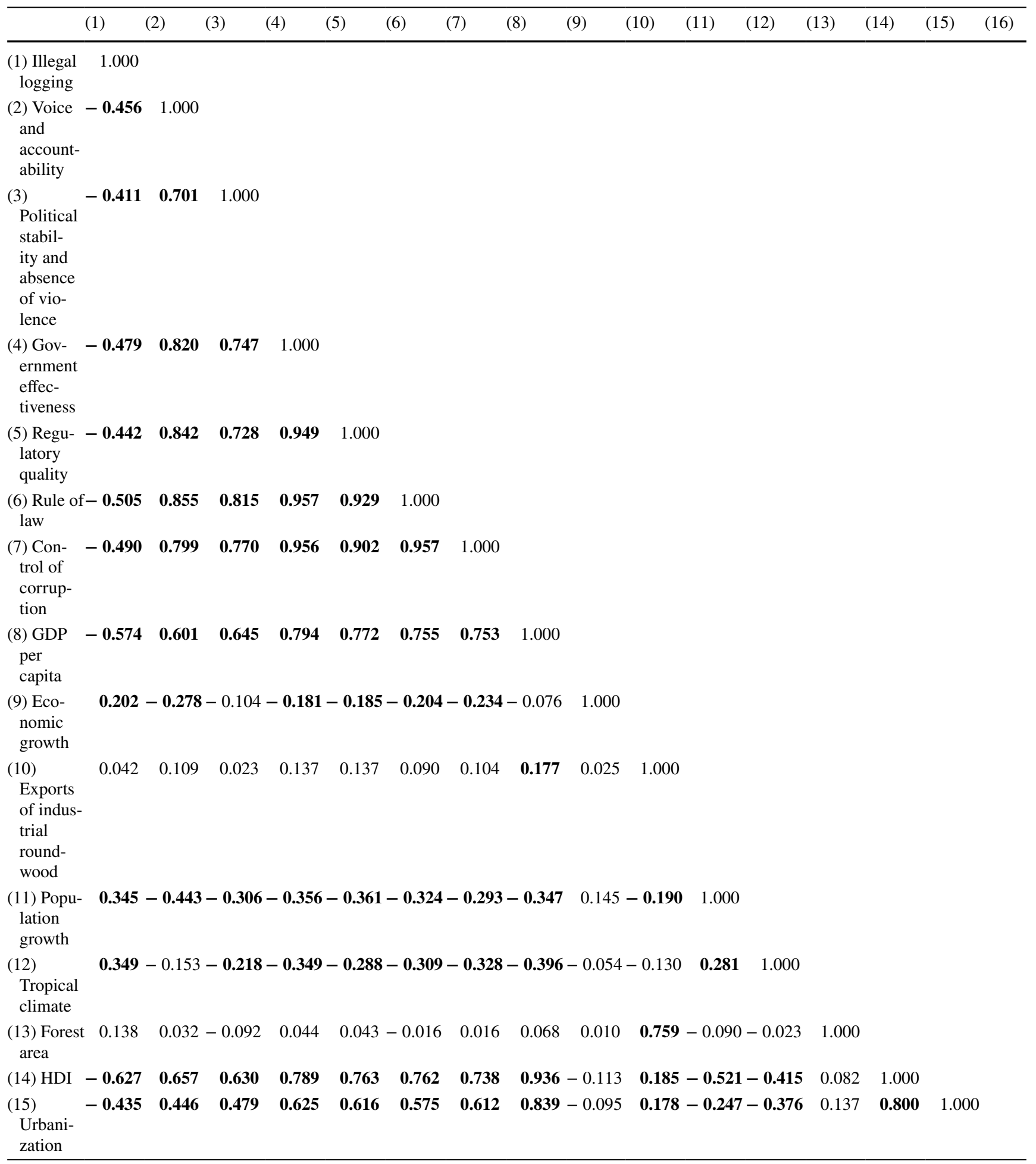




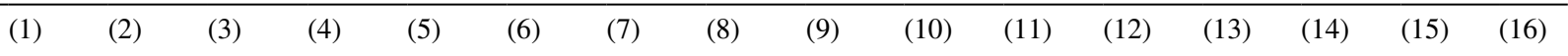

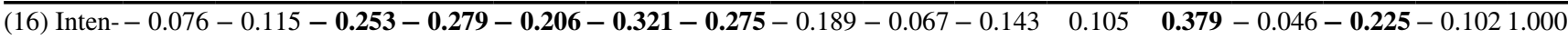
tional

homi-

cides

HDI: Human Development Index (2000-2004). Source: UNDP (2017).

Urbanization: urban population (\% of total; 2000-2004). Source: World Bank (2021).

Intentional homicides: intentional homicides per 100,000 people (2000-2004). Source: UNODC (2020).

\section{Appendix 3: Ordinary least squares regression results (robustness check)}

\begin{tabular}{|c|c|c|c|c|c|c|}
\hline Variables & Specification 1 & Specification 2 & Specification 3 & Specification 4 & Specification 5 & Specification 6 \\
\hline Constant & $\begin{array}{l}0.609 * * * \\
(0.084)\end{array}$ & $\begin{array}{l}0.635^{* * * *} \\
(0.089)\end{array}$ & $\begin{array}{l}0.586^{* * * *} \\
(0.102)\end{array}$ & $\begin{array}{l}0.598 * * * \\
(0.101)\end{array}$ & $\begin{array}{l}0.528 * * * \\
(0.097)\end{array}$ & $\begin{array}{l}0.534 * * * \\
(0.097)\end{array}$ \\
\hline $\begin{array}{l}\text { Voice and } \\
\text { accountability }\end{array}$ & $\begin{array}{l}-0.020^{*} \\
(0.011)\end{array}$ & & & & & \\
\hline $\begin{array}{l}\text { Political stability } \\
\text { and absence of } \\
\text { violence }\end{array}$ & & $\begin{array}{l}-0.010 \\
(0.011)\end{array}$ & & & & \\
\hline $\begin{array}{l}\text { Government } \\
\text { effectiveness }\end{array}$ & & & $\begin{array}{l}-0.018 \\
(0.014)\end{array}$ & & & \\
\hline $\begin{array}{l}\text { Regulatory qual- } \\
\text { ity }\end{array}$ & & & & $\begin{array}{l}-0.016 \\
(0.014)\end{array}$ & & \\
\hline $\begin{array}{l}\text { Rule of law } \\
\text { Control of cor- } \\
\text { ruption }\end{array}$ & & & & & $\begin{array}{l}-0.030^{* *} \\
(0.013)\end{array}$ & $\begin{array}{l}-0.029 * * \\
(0.012)\end{array}$ \\
\hline GDP per capita & $\begin{array}{l}-0.056^{* * *} \\
(0.009)\end{array}$ & $\begin{array}{l}-0.060 * * * \\
(0.009)\end{array}$ & $\begin{array}{l}-0.054 * * * \\
(0.011)\end{array}$ & $\begin{array}{l}-0.055^{* * *} \\
(0.011)\end{array}$ & $\begin{array}{l}-0.047 * * * \\
(0.010)\end{array}$ & $\begin{array}{l}-0.048^{* * *} \\
(0.010)\end{array}$ \\
\hline Economic growth & $\begin{array}{l}0.007 * * * \\
(0.002)\end{array}$ & $\begin{array}{l}0.008 * * * \\
(0.002)\end{array}$ & $\begin{array}{l}0.007 * * * \\
(0.002)\end{array}$ & $\begin{array}{l}0.007 * * * \\
(0.002)\end{array}$ & $\begin{array}{l}0.007 * * * \\
(0.002)\end{array}$ & $\begin{array}{l}0.006 * * * \\
(0.002)\end{array}$ \\
\hline $\begin{array}{l}\text { Exports of indus- } \\
\text { trial roundwood }\end{array}$ & $\begin{array}{l}0.001 \\
(0.005)\end{array}$ & $\begin{array}{l}0.001 \\
(0.005)\end{array}$ & $\begin{array}{l}0.001 \\
(0.005)\end{array}$ & $\begin{array}{l}0.001 \\
(0.005)\end{array}$ & $\begin{array}{l}0.002 \\
(0.005)\end{array}$ & $\begin{array}{l}0.001 \\
(0.005)\end{array}$ \\
\hline $\begin{array}{l}\text { Population } \\
\text { growth }\end{array}$ & $\begin{array}{l}-0.011 \\
(0.007)\end{array}$ & $\begin{array}{l}-0.008 \\
(0.007)\end{array}$ & $\begin{array}{l}-0.008 \\
(0.007)\end{array}$ & $\begin{array}{l}-0.008 \\
(0.007)\end{array}$ & $\begin{array}{l}-0.008 \\
(0.007)\end{array}$ & $\begin{array}{l}-0.007 \\
(0.007)\end{array}$ \\
\hline Tropical climate & $\begin{array}{l}0.001 * * * \\
(>0.000)\end{array}$ & $\begin{array}{l}0.001 * * * \\
(>0.000)\end{array}$ & $\begin{array}{l}0.001 * * * \\
(>0.000)\end{array}$ & $\begin{array}{l}0.001 * * * \\
(>0.000)\end{array}$ & $\begin{array}{l}0.001 * * * \\
(>0.000)\end{array}$ & $\begin{array}{l}0.001 * * * \\
(>0.000)\end{array}$ \\
\hline Forest area & $\begin{array}{l}>0.000 \\
(>0.000)\end{array}$ & $\begin{array}{l}>0.000 \\
(>0.000)\end{array}$ & $\begin{array}{l}>0.000 \\
(>0.000)\end{array}$ & $\begin{array}{l}>0.000 \\
(>0.000)\end{array}$ & $\begin{array}{l}>0.000 \\
(>0.000)\end{array}$ & $\begin{array}{l}>0.000 \\
(>0.000)\end{array}$ \\
\hline $\mathrm{N}$ & 163 & 163 & 163 & 163 & 163 & 163 \\
\hline $\mathrm{R}^{2}$ & 0.543 & 0.536 & 0.539 & 0.538 & 0.550 & 0.549 \\
\hline
\end{tabular}

*Significant at the $10 \%$ level

**Significant at the $5 \%$ level

*** Significant at the $1 \%$ level. Unstandardized coefficients and standard errors in parentheses 
Authors' contributions Matthias Bösch is the sole author of this paper.

Funding Open Access funding enabled and organized by Projekt DEAL. This research did not receive any specific grant from funding agencies in the public, commercial or not-for-profit sectors

Availability of data and material The datasets generated and analysed during the current study are available from the author upon reasonable request.Code availability Not applicable.

\section{Declarations}

Conflicts of interest The author declares that he has no conflict of interest.

Open Access This article is licensed under a Creative Commons Attribution 4.0 International License, which permits use, sharing, adaptation, distribution and reproduction in any medium or format, as long as you give appropriate credit to the original author(s) and the source, provide a link to the Creative Commons licence, and indicate if changes were made. The images or other third party material in this article are included in the article's Creative Commons licence, unless indicated otherwise in a credit line to the material. If material is not included in the article's Creative Commons licence and your intended use is not permitted by statutory regulation or exceeds the permitted use, you will need to obtain permission directly from the copyright holder. To view a copy of this licence, visit http://creativecommons.org/licenses/by/4.0/.

\section{References}

Alemagi D, Kozak RA (2010) Illegal logging in Cameroon: causes and the path forward. Forest Policy Econ 12:554-561

Allison PD (2012) Logistic regression using SAS: theory and application, 2nd edn. SAS Institute Inc., Cary

Angelsen A, Kaimowitz D (1999) Rethinking the causes of deforestation: lessons from economic models. World Bank Res Obs 14:73-98

Barbier EB, Burgess JC, Folke C (2019) Paradise lost? The ecological economics of biodiversity, Routledge, London and New York

Béguin A, Hales S, Rocklöv J, Astrom C, Louis VR, Sauerborn R (2011) The opposing effects of climate change and socio-economic development on the global distribution of malaria. Glob Environ Chang 21:1209-1214

Bösch M, Elsasser P, Franz K, Lorenz M, Moning C, Olschewski R, Rödl A, Schneider H, Schröppel B, Weller P (2018) Forest ecosystem services in rural areas of Germany: insights from the national TEEB study. Ecosyst Serv 31:77-83

Bösch M, Elsasser P, Wunder S (2019) Why do payments for watershed services emerge? A cross-country analysis of adoption contexts. World Dev 119:111-119

Brack D (2003) Illegal logging and the illegal trade in forest and timber products. Int For Rev 5:195-198

Brack D (2005) Controlling illegal logging and the trade in illegally harvested timber: the EU's Forest Law Enforcement, Governance and Trade Initiative. Rev Eur Comp Int Environ Law 14:28-38
Buil I, de Chernatony L, Martínez E (2012) Methodological issues in cross-cultural research: an overview and recommendations. J Target Meas Anal Mark 20:223-234

Burgess JC (1993) Timber production, timber trade and tropical deforestation. Ambio 22:136-143

Burgess R, Miguel E, Stanton C (2015) War and deforestation in Sierra Leone. Environ Res Lett 10:090514

Contreras-Hermosilla A (2002) Law compliance in the forestry sector: an overview. WBI Working Papers. World Bank Institute, Washington, D.C.

Contreras-Hermosilla A, Doornbosch R, Lodge M (2007) The economics of illegal logging and associated trade. Organisation for Economic Co-operation and Development, Paris

Culas R, Dutta D (2003) A re-examination of causes of deforestation and environmental Kuznets curve: evidence from Latin America, Africa and Asia. Working Papers, School of Economics and Political Science, University of Sydney

Dahlberg S, Holmberg S, Rothstein B, Alvarado Pachon N, Axelsson S (2020) The Quality of Government Basic Dataset (2020). The Quality of Government Institute, University of Gothenburg. http:// www.qog.pol.gu.se. Accessed 15 Sept 2020

Deacon RT (1994) Deforestation and the rule of law in a cross-section of countries. Land Econ 70:414-430

Dieter M (2009) Analysis of trade in illegally harvested timber: accounting for trade via third party countries. Forest Policy Econ 11:600-607

Dieter M, Englert H, Weimar H (2012) Wood from illegal harvesting in EU markets: estimations and open issues. Landbauforschung 62:247-254

Ehrhardt-Martinez K, Crenshaw EM, Jenkins JC (2002) Deforestation and the environmental Kuznets curve: a cross-national investigation of intervening mechanisms. Soc Sci Q 83:226-243

FAO (2001) State of the world's forests 2001. Food and Agriculture Organization of the United Nations, Rome

FAO (2021) FAOSTAT database. http://www.fao.org/faostat/en/\#home. Accessed 8 Jan 2021

Gan J, Cerutti PO, Masiero M, Pettenella D, Andrighetto N, Dawson T (2016) Quantifying illegal logging and related timber trade. In: Kleinschmit D, Mansourian S, Wildburger C, Purret A (eds) Illegal logging and related timber trade-dimensions, drivers, impacts and responses. A global scientific rapid response assessment report, IUFRO World Series, vol 35. IUFRO, Vienna, pp $37-60$

Geist HJ, Lambin EF (2002) Proximate causes and underlying driving forces of tropical deforestation. Bioscience 52:143-150

Glastra R (1999) Cut and run: illegal logging and timber trade in the tropics. International Development Research Centre, Ottawa

Hansen CP, Treue T (2008) Assessing illegal logging in Ghana. Int For Rev 10:573-590

Harper JK, Rister EM, Mjelde JW, Drees BM, Way MO (1990) Factors influencing the adoption of insect management technology. Am J Agr Econ 72:997-1005

Hiller MA, Jarvis BC, Hikma L, Paulson LJ, Pollard EHB, Stanley SA (2004) Recent trends in illegal logging and a brief discussion of their causes. J Sustain For 19:181-212

Hoare A (2015) Tackling illegal logging and the related trade: what progress and where next? Chatham House Report, Chatham House, London

Humphreys D (2006) Logjam: deforestation and the crisis of global governance. Earthscan, London

Islam KK, Sato N (2012) Deforestation, land conversion and illegal logging in Bangladesh: the case of the Sal (Shorea robusta) forests. iForest 5:171-178

Kaimowitz D (2003) Forest law enforcement and rural livelihoods. Int For Rev 5:199-210 
Kant S, Redantz A (1997) An econometric model of tropical deforestation. J For Econ 3:51-86

Karsenty A (2003) Underlying causes of the rapid expansion of illegal exploitation of tropical timber. Int For Rev 5:236-239

Kaufmann D, Kraay A, Mastruzzi M (2011) The Worldwide Governance Indicators: methodological and analytical issues. Hague J Rule Law 3:220-246

Kleinschmit D, Leipold S, Sotirov M (2016a) Introduction: understanding the complexities of illegal logging and associated timber trade. In: Kleinschmit D, Mansourian S, Wildburger C, Purret A (eds) Illegal logging and related timber trade-dimensions, drivers, impacts and responses. A global scientific rapid response assessment report, IUFRO World Series, vol 35. IUFRO, Vienna, pp $13-22$

Kleinschmit D, Mansourian S, Wildburger C, Purret A (eds) (2016b) Illegal logging and related timber trade-dimensions, drivers, impacts and responses. A global scientific rapid response assessment report, IUFRO World Series, vol 35. IUFRO, Vienna

Köthke M (2020) Implementation of the European Timber Regulation by German importing operators: an empirical investigation. Forest Policy Econ 111:102028

Lambin EF, Meyfroidt P, Rueda X, Blackman A, Börner J, Cerutti PO, Dietsch T, Jungmann L, Lamarque P, Lister J, Walker NF, Wunder S (2014) Effectiveness and synergies of policy instruments for land use governance in tropical regions. Glob Environ Chang 28:129-140

Landholm DM, Pradhan P, Kropp JP (2019) Diverging forest land use dynamics induced by armed conflict across the tropics. Glob Environ Chang 56:86-94

Lawson S, MacFaul L (2010) Illegal logging and related trade: indicators of the global response. Chatham House, London

Leipold S (2017) How to move companies to source responsibly? German implementation of the European Timber Regulation between persuasion and coercion. Forest Policy Econ 82:41-51

Leipold S, Winkel G (2016) Divide and conquer - discursive agency in the politics of illegal logging in the United States. Glob Environ Chang 36:35-45

Leipold S, Sotirov M, Frei T, Winkel G (2016) Protecting „First world“ markets and "Third world" nature: the politics of illegal logging in Australia, the European Union and the United States. Glob Environ Chang 39:294-304

Li R, Buongiorno J, Turner JA, Zhu S, Prestemon J (2008) Long-term effects of eliminating illegal logging on the world forest industries, trade, and inventory. Forest Policy Econ 10:480-490

McElwee P (2004) You say illegal, I say legal. J Sustain For 19:97-135

Meehan F, Tacconi L (2017) A framework to assess the impacts of corruption on forests and prioritize responses. Land Use Policy 60(113): 122

Menard SW (2010) Logistic regression: from introductory to advanced concepts and applications. Sage, Thousand Oaks

Miller MJ (2011) Persistent illegal logging in Costa Rica: the role of corruption among forestry regulators. J Environ Dev 20:50-68

Miller F, Taylor R, White G (2006) Keep it legal: best practices for keeping illegally harvested timber out of your supply chain. WWF Global Forest \& Trade Network, Gland

Nellemann C, Programme IEC (eds) (2012) Green carbon, black trade: illegal logging, tax fraud and laundering in the world's tropical forests. A rapid response assessment . United Nations Environment Programme, Arendal

Nunn N, Puga D (2012) Ruggedness: the blessing of bad geography in Africa. Rev Econ Stat 94:20-36

Palmer C (2001) The extent and causes of illegal logging: an analysis of a major cause of tropical deforestation in Indonesia. CSERGE Working Paper, Economics Department University College London and Centre for Social and Economic Research on the Global
Environment, University College London and University of East Anglia

Pampel FC (2000) Logistic regression: a primer. Sage, Thousand Oaks

Pokorny B, Pacheco P, Cerutti PO, van Solinge TB, Kissinger G, Tacconi L (2016) Drivers of illegal and destructive forest use. In: Kleinschmit D, Mansourian S, Wildburger C, Purret A (eds) Illegal logging and related timber trade-dimensions, drivers, impacts and responses. A global scientific rapid response assessment report, IUFRO World Series, vol 35. IUFRO, Vienna, pp $61-80$

Ravenel RM, Granoff IME (2004) Illegal logging in the tropics. J Sustain For 19:351-371

Reboredo F (2013) Socio-economic, environmental, and governance impacts of illegal logging. Environ Syst Decis 33:295-304

Richards M, Wells A, del Gatto F, Contreras-Hermosilla A, Pommier D (2003) Impacts of illegality and barriers to legality: a diagnostic analysis of illegal logging in Honduras and Nicaragua. Int For Rev 5:282-292

Rudel T, Roper J (1996) Regional patterns and historical trends in tropical deforestation, 1976-1990: a qualitative comparative analysis. Ambio 25:160-166

Rudel T, Roper J (1997a) Forest fragmentation in the humid tropics: a cross-national analysis. Singap J Trop Geogr 18:99-109

Rudel T, Roper J (1997b) The paths to rain forest destruction: crossnational patterns of tropical deforestation, 1975-90. World Dev 25:53-65

Scheuch EK (1993) The cross-cultural use of sample surveys: problems of comparability. Hist Soc Res 18:104-138

Schloenhardt A (2008) The illegal trade in timber and timber products in the Asia-Pacific region. Research and Public Policy Series No. 89. Australian Institute of Criminology, Canberra

Seneca Creek Associates and Wood Resources International (2004a) "Illegal" logging and global wood markets: the competitive impacts on the U.S. wood products industry. Seneca Creek Associates, Poolesville

Seneca Creek Associates and Wood Resources International (2004b) Summary - "Illegal" logging and global wood markets: the competitive impacts on the U.S. wood products industry. Seneca Creek Associates, Poolesville

Shandra JM (2007) International Nongovernmental Organizations and deforestation: good, bad, or irrelevant? Soc Sci Q 88:665-689

Shandra JM, Shor E, Maynard G, London B (2008) Debt, structural adjustment, and deforestation: a cross-national study. Journal of World-Systems Research 14:1-21

Shandra JM, Shircliff E, London B (2011) The International Monetary Fund, World Bank, and structural adjustment: a cross-national analysis of forest loss. Soc Sci Res 40:210-225

Shandra JM, Esparza LE, London B (2012) Nongovernmental Organizations, democracy, and deforestation: a cross-national analysis. Soc Nat Resour 25:251-269

Sikor T, To PX (2011) Illegal logging in Vietnam: Lam Tac (forest hijackers) in practices and talk. Soc Nat Resour 24:688-701

Smith W (2004) Undercutting sustainability. J Sustain For 19:7-30

Smith J, Obidzinski K, Subarudi S, Suramenggala I (2003) Illegal logging, collusive corruption and fragmented governments in Kalimantan, Indonesia. Int For Rev 5:293-302

Sommer JM (2017) Grand and petty corruption: a cross-national analysis of forest loss in low- and middle-income nations. Environ Sociol 3:414-426

Sommer JM (2018) Corrupt actions and forest loss: a cross-national analysis. Int J Soc Sci Stud 6:23-34

Tabachnick BG, Fidell LS (2013) Using multivariate statistics, 6th edn. Pearson, Harlow

Tacconi L (2007c) Illegal logging and the future of the forest. In: Tacconi L (ed) Illegal logging: law enforcement, livelihoods and the timber trade. Earthscan, London, pp 275-290 
Tacconi L (2007d) Decentralization, forests and livelihoods: Theory and narrative. Glob Environ Chang 17:338-348

Tacconi L (ed) (2007a) Illegal logging: law enforcement, livelihoods and the timber trade. Earthscan, London

Tacconi L (2007b) The problem of illegal logging. In: Tacconi L (ed) Illegal logging: law enforcement, livelihoods and the timber trade. Earthscan, London, pp 1-16

Tallis H, Goldman R, Uhl M, Brosi B (2009) Integrating conservation and development in the field: implementing ecosystem service projects. Front Ecol Environ 7:12-20

Tole L (1998) Sources of deforestation in tropical developing countries. Environ Manag 22:19-33

Toyne P, O'Brien C, Nelson R (2002) The timber footprint of the G8 and China: making the case for green procurement by government. WWF International, Gland

Turner JA, Katz A, Buongiorno J (2007) Implications for the New Zealand wood products sector of trade distortions due to illegal logging. A Report Prepared for the Ministry of Agriculture and Forestry, New Zealand

Turner JA, Katz A, Buongiorno J (2008) The economic implications of illegal logging for the New Zealand forest sector. N Z J For $53: 20-25$

UNDP (2017) Human Development Data, 1990-2017. http://hdr.undp. org/en/data. Accessed 15 September 2019

UNODC (2020) Intentional homicide victims, counts and rates per 100,000 population. https://dataunodc.un.org/crime/intentionalhomicide-victims. Accessed 15 September 2020

van Solinge TB (2014) Researching illegal logging and deforestation. Int J Crime Justice Soc Democr 3:35-48
Vasco C, Torres B, Pacheco P, Griess V (2017) The socioeconomic determinants of legal and illegal smallholder logging: evidence from the Ecuadorian Amazon. Forest Policy Econ 78:133-140

WGI (2018) World Governance Indicators dataset, 2018 update. https:// info.worldbank.org/governance/wgi/\#home. Accessed 15 Sept 2019

World Bank (2006) Strengthening forest law enforcement and governance - addressing a systemic constraint to sustainable development. Report No. 36638-GLB, The World Bank, Washington D.C.

World Bank (2021) World Bank Open Data. https://data.worldbank. org. Accessed 15 January 2021

WWF (2005) Failing the forests-Europe's illegal timber trade. WWFUK, Godalming

Zanella MA, Schleyer C, Speelman S (2014) Why do farmers join Payments for Ecosystem Services (PES) schemes? An assessment of PES water scheme participation in Brazil. Ecol Econ 105:166-176

Zbinden S, Lee DR (2005) Paying for environmental services: an analysis of participation in Costa Rica's PSA program. World Dev 33:255-272

Zimmerman BL, Kormos CF (2012) Prospects for sustainable logging in tropical forests. Bioscience 62:479-487

Publisher's Note Springer Nature remains neutral with regard to jurisdictional claims in published maps and institutional affiliations. 